\title{
Influence of obesity gene in quantitative traits of swine
}

\author{
Graciele Segantini do Nascimento Borges and Luiz Ricardo Goulart \\ Laboratório de Genética Molecular, Instituto de Genética e Bioquímica, Universidade Federal de \\ Uberlândia, Uberlândia, MG, Brasil.
}

\begin{abstract}
Genotype data of 477 animals of several swine races (Landrace - LD, Large White - LW, Pietrain - PI, LWXLDXPI, Piau, Monteiro, and unknown race) were obtained to determine the allele frequency of the obesity gene. Genotype data of 174 crossbred swine (LWXLDXPI) were also obtained, in order to assess its correlation with carcass evaluation data (lean meat percentage, backfat thickness at P2, loin eye area, adjacent fat area, total fat and meat). Finally, genotype data of 96 pure swine (Landrace, Large White and Pietrain) were collected, to establish its relation with meat quality (drip loss, meat color, texture analysis and intramuscular fat) and carcass evaluation data (lean meat percentage; ham, loin, shoulder and belly weights; and backfat thickness at P2). This work also aimed associating EPDs (expected progeny differences) for litter size, daily weight gain and backfat thickness with genotype data of 49 Large White males and 54 Landrace females. Genotyping was done on animal blood by PCR-RFLP, based on Stratil et al. (1997). Statistical analysis was done by using SAS software for variance analysis between genotypes and data for each cited class. For purebred animals, a mixed model was used, with sire within race as random effect. The allelic frequencies of alleles $T$ and $C$ were, respectively: $0.8142 ; 0.1857$ (Landrace); 0.9125 ; 0.0875 (Large White); 0.9433 ; 0.0566 (Pietrain); 0.8333; 0.1666 (LWXLDXPI); 0.2500; 0.7500 (Piau); $0.8750 ; 0.1250$ (Monteiro), and $0.8870 ; 0.1130$ (unknown race). Since the highest allele $C$ frequency occurred in Piau, we suggest that this allele could be associated with fat accumulation. In the Landrace race, a study was done separating the frequencies of 2 generations (great-grandfather and grandfather), and the differences confirmed by a Chi-square test, a higher frequency of allele $\mathrm{C}$ having been found in the grandparental generation. This suggests that this allele could be eliminated by selection from the great-grandparental generation, when the male grandparent is replaced by the great-grandparental generation. The obesity gene did not influence any of the carcass evaluation data from crossbred animals. In pure swine, where the only genotypes were TT and TC, it greatly influenced shoulder weight and meat texture, with the highest average in heterozygotes (shoulder: $4.07 \mathrm{vs} .3 .93$; texture: $2.62 \mathrm{vs.} 1.82$ ), suggesting better carcass quality and worse meat quality than in homozygotes. The obesity gene did not influence any trait in the expected progeny difference (EPD) study.
\end{abstract}

Key words: obese gene, leptin gene, quantitative traits.

Received: March 3, 2002; accepted: March 25, 2002.

\section{Introduction}

Obesity, a chronic imbalance between energy intake and expenditure, is a multifactorial pathology involving complex interactions of genetic and environmental factors (Cusin et al.,1995). As yet, it lacks specific therapy.

Although obesity per se is not a major concern in animal agriculture, to alter body composition by combining nutrients which favor lean protein accretion, thus improving production efficiency and satisfying both consumer and industrial demands, is a major goal of animal scientists (Houseknecht et al., 1998).

Send correspondence to L.R.Goulart. Laboratório de Genética Molecular, Instituto de Genética e Bioquímica, Bloco 2E - Sala 24, UFU, 38400-902 Uberlândia, MG, Brazil. E-mail: Irgoulart@ufu.br.
In earlier studies on obesity in animals, it was believed that genetically obese individuals would present defects in the $o b$ gene (mutation), in leptin receptors or in signaling pathways triggered by receptors (Barinaga, 1996).

In livestock animals, the goal is still to identify the complete sequence of one of all genes carrying identified mutations responsible for the disease; the obese gene has recently been cloned for mice, human, and swine (Bidwell et al.,1997).

The $o b$ gene codes for a protein named leptin that is produced by adipocytes (fat-storage cells) and circulates in the blood (Zhang et al., 1994). Its physiological function is still obscure, but it is thought that this hormone signals satiety, maintaining stability of body fat mass. In practice, loss 
of body fat leads to leptin decrease, which in turn leads to a positive energy-balance (Friedman, 1997).

Studies have shown that in some mice absence of leptin causes severe obesity, that can be reduced by exogenous administration of the hormone (Pelleymonter et al., 1995). But in swine the function of the obese gene and its expression in physiology/growth is currently unknown. However, experiments confirmed the hypothesis that porcine leptin expression varies with propensity for adipose tissue deposition (Ramsay et al., 1998).

In the hog industry, carcass weight, percentage of lean meat, cut yields and meat quality determine the price. In Brazil, hog producers are currently paid according to weight and lean meat percentage based on backfat thickness (Upnmoor, 1997).

Visscher and Haley (1998) state that molecular markers hold great potential for swine improvement programs, stressing marker use when the normal selection is not effective, e.g., for traits restricted to sex or carcass.

The aim of this work was to find some relation between the swine obese gene polymorphism and quantitative traits.

\section{Materials and Methods}

The objective of this work was to determine the allele frequency of the obesity gene in several swine races (Landrace, Large White, Pietrain, LWXLDXPI, Piau, Monteiro and an unknown race), using a total of 477 animals. It further proposed to associate the obesity gene genotype with carcass evaluation data (lean meat percentage, backfat thickness at P2, loin eye area, adjacent fat area, total fat and meat) in 174 crossbred swine (LWXLDXPI), with both meat quality (drip loss, meat color, texture analysis and intramuscular fat) and carcass evaluation data (lean meat percentage; ham, loin, shoulder and belly weights; and backfat thickness at P2) in 96 pure swine (Landrace, Large White and Pietrain). It intended to associate EPDs (expected progeny differences) for litter size (LS), daily weight gain (DWG) and backfat thickness (BT) in 49 Large White males and 54 Landrace females (Table I).

Backfat thickness was evaluated because it is related to the quality of swine meat: the greater the lean meat yield, the higher the carcass value. Meat quality and carcass evaluation data were used because the obese gene may be

Table I - Race, data and individuals (n) used in this experiment.

\begin{tabular}{llc}
\hline Race & Data & $\mathrm{n}$ \\
\hline Many races & Genotype & 477 \\
$\begin{array}{l}\text { LD, LW, PI - } \\
\text { grandparents }\end{array}$ & Meat quality and carcass evaluation & 96 \\
LW X LD X PI & Carcass evaluation & 174 \\
Landrace females & EPDs LS, BT and DWG & 54 \\
Large white males & EPDs LS, BT and DWG & 49 \\
\hline
\end{tabular}

related with backfat, so it could affect these traits. Furthermore, this study was important because there was a chance of finding a marker in the obesity gene to be used in a MAS (Marker Assisted Selection) program like the one of the Halothane gene, allowing exclusion of undesirable traits in animal crossbreeding.

Litter size data was evaluated because leptin is a signal for the reproductive system, and daily weight gain was measured because of the correlation between feed intake and obesity.

\section{Genotyping for the ob gene}

Genotyping was done on animal blood by PCR-RFLP, based on Stratil et al. (1997), using a pair of primers which amplified a 152-base-pair sequence in the swine gene. Following amplification of the genomic DNA, PCR products were digested with HinfI and electrophoresed in 3.5\% agarose gel; the DNA bands were visualized by ethidium bromide staining of the gel. Two alleles were detected: allele $\mathrm{T}$ - fragment $152 \mathrm{bp}$ (uncut), and allele $\mathrm{C}$ fragments 68 and $84 \mathrm{bp}$.

\section{Crossbred animals (PIXLDXLW) (Antunes, 1997)}

A hundred and seventy-four swine, including castrated males and females, were slaughtered, and their carcasses dissected into meat, bone, fat, skin and offal, weighed separately. In this experiment, data were collected for only lean meat percentage; backfat thickness at P2; loin eye and adjacent fat area; and total fat and meat data, since, according to Felício et al. (1986), these traits are highly correlated with leanness.

\section{Purebred animals (Franco, 1999)}

Ninety-six animal carcasses including the Pietrain, Landrace and Large White races, with 16 uncastrated males and 16 females of each race, were analyzed. Data used to test the effect of the obesity genotype were: dissected carcasses; lean meat percentage; ham, loin, shoulder and belly weights; and backfat thickness at P2.

Meat quality data were obtained by analyzing functional properties, e.g., drip loss, meat color, texture and intramuscular fat.

\section{Expected progeny differences $x$ obese genotyping}

Fifty-four Landrace females and forty-nine Large White males were genotyped together with EPDs data to compare obesity genotyping for litter size, daily weight gain and backfat thickness.

\section{Statistical analysis}

Statistical analysis was done by using SAS software, release 6.12 (1996), on variance between genotypes and the data for each cited class.

For crossbred animals, the following model was used: 
$\mathrm{Y}_{\mathrm{ij}}=\mu+\mathrm{G}_{\mathrm{i}}+\mathrm{S}_{\mathrm{j}}+\beta\left(\mathrm{X}_{\mathrm{ij}}-\mathrm{X} ..\right)+\mathrm{e}_{\mathrm{ij}}$

$Y_{\mathrm{ij}}$ : traits observed (lean meat percentage [LMP], backfat thickness [BT], loin eye area, total fat and meat) in $\mathrm{i}^{\text {th }}$ genotype and $\mathrm{j}^{\text {th }}$ sex.

$\mu$ : sum of least square means.

$\mathrm{G}_{\mathrm{i}}$ : genotype with $\mathrm{i}$ value 0,1 or $2: 0=\mathrm{CC}, 1=\mathrm{TC}, 2=$ TT.

$S_{j}$ : sex, with $\mathrm{j}$ value 1 or $2: 1=$ male and $2=$ female.

$\mathrm{e}_{\mathrm{ij}}$ : random error with normal distribution, and independently distributed with zero mean and $\sigma^{2}$ variance.

Carcass weight was used as covariance.

For pure animals, the following mixed model was used:

$\mathrm{Y}_{\mathrm{ij}}=\mu+\mathrm{P}_{\mathrm{i}}\left(\mathrm{R}_{\mathrm{k}}\right)+\mathrm{G}_{\mathrm{i}}+\mathrm{S}_{\mathrm{j}}+\mathrm{R}_{\mathrm{k}}+\beta\left(\mathrm{X}_{\mathrm{ijk}}-\mathrm{X} \ldots\right)+\mathrm{e}_{\mathrm{ijk}}$

$\mathrm{Y}_{\mathrm{ij}}$ : traits observed (lean meat percentage [LMP]; backfat thickness [BT]; ham, loin, shoulder and belly weights; water retention ability [WRA]; texture; L, A and B colors; intramuscular fat) in $i^{\text {th }}$ genotype and $\mathrm{j}^{\text {th }}$ sex.

$\mu$ : sum of least square means.

$\mathrm{P}_{\mathrm{i}}\left(\mathrm{R}_{\mathrm{k}}\right)$ : sire within race as random effect.

$\mathrm{G}_{\mathrm{i}}$ : genotype with i value 1 or $2: 1=\mathrm{TT}$ and $2=\mathrm{TC}$.

$S_{\mathrm{j}}$ : sex with $\mathrm{j}$ value 1 or $2: 1=$ male and $2=$ female.

$\mathrm{R}_{\mathrm{k}}$ : race with $\mathrm{K}$ value 1,2 or $3: 1=$ Pietrain, $2=$ Large White and $3=$ Landrace.

$\mathrm{e}_{\mathrm{ij}}$ : random error with normal distribution, and independently distributed with zero mean and $\sigma^{2}$ variance.

Carcass weight was used as covariance.

In Landrace females and Large White males, EPD estimates (DWG, BT and LS) were used, obtained by a complete animal model under BLUP.

$\mathrm{Y}_{\mathrm{i}=} \mu+\mathrm{G}_{\mathrm{i}}+\mathrm{e}_{\mathrm{i}}$

$\mathrm{Y}_{\mathrm{ijk}}$ : observation of traits (EPD DWG, EPD BT or EPD LS) in $\mathrm{i}^{\text {th }}$ genotype.

$\mu$ : sum of square means.

$\mathrm{G}_{\mathrm{i}}$ : genotype with $\mathrm{i}$ value 1 or $2: 1=\mathrm{TT}$ and $2=\mathrm{TC}$.

$\mathrm{e}_{\mathrm{i}}$ : random error with normal distribution, and independently distributed with zero mean and $\sigma^{2}$ variance.

\section{Results and Discussion}

DNA bands observed were according to Stratil et al. (1997).

The genotyping observed in Figure 1 demonstrates the two most common genotypes: TT (only one $152 \mathrm{bp}$ band) and TC (3 bands; 152, 68 and 84 bp, respectively).

\section{Allele frequencies}

The respective frequencies of alleles $\mathrm{T}$ and $\mathrm{C}$ in different races were: 0.8142 and 0.1857 (Landrace); 0.9125 and 0.0875 (Large White); 0.9433 and 0.0566 (Pietrain); 0.8333 and 0.1666 (LWXLDXPI); 0.2500 and 0.7500

\section{$123456 \quad 7891011121314151617181920$}

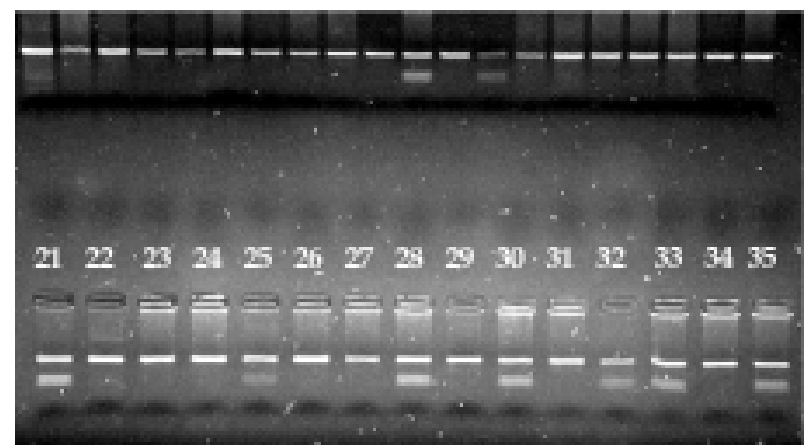

Figure 1 - Hinfl polymorphism in porcine $o b$ gene. TC-lanes 1, 11, 13, 21, $25,28,30,32,33$ e 35 ; TT - the other lanes.

(Piau); 0.8750 and 0.1250 (Monteiro); 0.8870 and 0.1130 (unknown race). The highest frequency of allele $\mathrm{C}$ was found in Piau, a Brazilian race with a strong tendency to accumulate fat (Cavalcanti, 1984), suggesting that this allele could be associated with fat accumulation.

Frequencies found by Stratil et al. (1997) were similar to those found in this work for Landrace, Large White and Pietrain.

The Landrace sample included animals of different generations; therefore, we separated the frequencies of the two generations (great-grandparent and male grandparent), to determine if this difference was due to selection. Chi-square data showed a significantly higher frequency for allele $\mathrm{C}$ in the grandparent generation, suggesting that this allele had been eliminated from the great- grandparent generation through selection.

\section{Crossbred animals}

The values for type III sum of squares and least square means obtained in the variance analysis for carcass evaluation traits are presented in Tables II, III and IV, respectively.

Sex was statistically significant for all traits, but carcass weight did not influence the lean meat percentage, findings similar to the results obtained by Antunes (1997).

The obesity gene did not influence any crossbred carcass evaluation data.

Females showed results suggesting better carcass quality than castrate males, since the loin eye area was significantly bigger and the backfat thickness and fat significantly lower $(p<0,01)$ than in males. Meat amount and percentage in females were also significantly higher, as shown by Antunes (1997), Ellis et al., (1996) and Elizondo et al., (1976).

\section{Purebred animals}

The values for type III sum of squares obtained in the variance analysis for carcass evaluation and meat quality traits are presented in Tables V and VI. 
Table II - Variance analysis for carcass evaluation traits with effects of carcass weight, sex and obesity genotype in crossbred animals.

\begin{tabular}{lcccccc}
\hline & & \multicolumn{3}{c}{ Type III SS } \\
\cline { 3 - 6 } Source & df & Lean meat percentage & Backfat thickness & Loin eye area & Fat & Total meat \\
\hline Weight & 1 & 3.1739 & $152.2993^{* *}$ & $1675.8868^{* *}$ & $443.9072^{* *}$ & $3208.8910^{* *}$ \\
Sex & 1 & $147.3594^{* *}$ & $135.4911^{* *}$ & $535.5417^{* *}$ & $57.5496^{* *}$ & $44.3204^{* *}$ \\
$o b$ gene & 2 & 2.8766 & 15.6809 & 7.6059 & 1.3646 & 18.4956 \\
Error & 169 & & & & \\
\hline Total & 173 & & & & \\
\hline
\end{tabular}

**Statistically significant at $1 \%$

Carcass weight was used as covariance.

Table III - Least square means of traits by sex effect and the probability of significance for $\mathrm{F}$ test in crossbred animals.

\begin{tabular}{lcccc}
\hline & & \multicolumn{2}{c}{ Sex } & \\
\cline { 3 - 4 } Trait & Unit & $\mathrm{F}$ & $\mathrm{M}$ & $\mathrm{P}>\mathrm{F}$ \\
\hline Lean meat percentage & $(\%)$ & 61.4841 & 59.5835 & 0.0001 \\
Backfat thickness & $(\mathrm{mm})$ & 14.1973 & 16.0198 & 0.0002 \\
Loin eye area & $\left(\mathrm{cm}^{2}\right)$ & 46.1453 & 42.5220 & 0.0001 \\
Fat & $(\mathrm{kg})$ & 10.2172 & 11.4049 & 0.0001 \\
\hline Total meat & $(\mathrm{kg})$ & 41.7193 & 40.6770 & 0.0015 \\
\hline
\end{tabular}

Table IV - Least square means of traits by genotype effect in crossbred animals.

\begin{tabular}{lcccc}
\hline & & \multicolumn{3}{c}{$o b$ Genotype } \\
\cline { 3 - 5 } Trait & Unit & TT & TC & CC \\
\hline Lean meat percentage & $(\%)$ & 60.8445 & 60.6948 & 60.0621 \\
Backfat thickness & $(\mathrm{mm})$ & 14.3882 & 14.5347 & 16.4027 \\
Loin eye area & $\left(\mathrm{cm}^{2}\right)$ & 44.3172 & 43.9014 & 44.7822 \\
Fat & $(\mathrm{kg})$ & 10.6048 & 10.6253 & 11.2030 \\
\hline Total meat & $(\mathrm{kg})$ & 41.7253 & 41.0420 & 40.8271 \\
\hline
\end{tabular}

In the carcass evaluation traits, the obesity gene had a significant effect on shoulder weight and meat quality (texture). For other traits, there was no significant effect of the gene, similarly to the results obtained by Hardje et al. (1998) for the backfat thickness trait. Using the same pair of primers in Pietrain, Landrace and Large White, these authors did not find any significant difference in backfat.

Weight had a significant influence on every carcass evaluation trait, except lean meat percentage (LMP). Regarding meat quality traits, it influenced only the water retention ability measured by drip loss.

Race had a significant effect on all carcass evaluation traits, as well as on meat quality traits, such as: drip loss, B color (yellowness) and intramuscular fat.

Sex also significantly influenced all carcass evaluation traits, except lean meat percentage and belly weight. As for meat quality traits, it influenced drip loss, L color (lightness) and B color.

Least square means of statistically significant traits for genotype, race and sex effects are presented in Tables VII, VIII and IX, respectively.

Considering genotype effects, for both shoulder weight and meat texture higher values were found in the

Table V - Variance analysis of carcass evaluation traits (LMP - lean meat percentage; BT - backfat thickness at P2; ham, loin, shoulder and belly weights), and meat quality traits (WRA - water retention ability; texture; L, A and B colors) by weight, sex and obesity genotype effects in purebred animals.

\begin{tabular}{|c|c|c|c|c|c|c|c|c|c|c|c|c|}
\hline \multirow[b]{2}{*}{ Source } & \multirow[b]{2}{*}{$\mathrm{df}$} & \multicolumn{11}{|c|}{ Type III SS } \\
\hline & & LMP & BT & Ham & Loin & Shoulder & Belly & WRA & Texture & L color & A color & B color \\
\hline Weight & 1 & 0.00 & $12.37 * *$ & $659.47 * *$ & $259.65^{* *}$ & $217.96^{* *}$ & $235.84 * *$ & $10.99 * *$ & 1.29 & 0.05 & 0.00 & 0.08 \\
\hline Race & 2 & $42.59 * *$ & $15.58^{* *}$ & $127.40 * *$ & $5.36^{*}$ & $16.80^{* *}$ & $10.59 * *$ & $17.94 * *$ & 1.71 & 1.05 & 1.29 & $4.19^{*}$ \\
\hline Sex & 1 & 0.67 & $13.38 * *$ & $18.71 * *$ & $12.67 * *$ & $27.67 * *$ & 0.02 & $13.14 * *$ & 3.90 & $13.86^{* *}$ & 1.93 & $10.44 * *$ \\
\hline$o b$ gene & 1 & 0.83 & 0.36 & 0.01 & 0.17 & $6.67^{*}$ & 2.66 & 0.04 & $4.80^{*}$ & 1.31 & 1.53 & 0.04 \\
\hline Error & $63^{\mathrm{a}}$ & & & & & & & & & & & \\
\hline Total & $68^{\mathrm{b}}$ & & & & & & & & & & & \\
\hline
\end{tabular}

${ }^{a}=$ For race effect means 17 .

$\mathrm{b}=$ For race effect means 22 .

*Statistically significant at $5 \%$.

**Statistically significant at $1 \%$.

Carcass weight was used as covariance. 
Table VI - Variance analysis of meat quality trait: intramuscular fat (IMF) by weight, race, sex and obesity genotype effects, in purebred animals.

\begin{tabular}{lcc}
\hline & & \multicolumn{1}{c}{ Type III SS } \\
\cline { 3 - 3 } Source & df & IMF \\
\hline Weight & 1 & 0.05 \\
Race & 1 & $5.62^{*}$ \\
Sex & 1 & 0.54 \\
$o b$ gene & 2 & 0.78 \\
Error & $36^{\mathrm{a}}$ & \\
\hline Total & $41^{\mathrm{b}}$ & \\
\hline
\end{tabular}

${ }^{\mathrm{a}}=$ For race effect means 13 .

$\mathrm{b}=$ For race effect means 18 .

heterozygote (TC) than in the homozygote (TT); however, no race or sex effects were found for these traits. Higher shoulder weight was accompanied by a lower belly weight, indicating better carcass quality. On the other hand, a higher texture value may indicate worse meat quality for the genotype with allele $\mathrm{C}$, since greater texture means tougher meat with less consumer value. These results are similar to those described by Upnmoor (1997) and Sellier (1995), emphasizing a significant negative correlation between meat quantity and quality, i.e., the higher the percentage of meat, the worse its quality. This conclusion is supported by Wood et al. (1986), who found less juice in leaner animals.

The Pietrain race presented the highest lean meat percentage, ham and shoulder weight (similar to Large White), drip loss, and intramuscular fat. The Large White race presented the greatest loin weight (similar to Landrace) and B color (similar to Pietrain); and the Landrace breed had the greatest backfat thickness and belly weight. These results
Table VII - Least square means of the traits, standard error values and significance probability of each trait by genotype effect, in purebred animals.

\begin{tabular}{lcccccc}
\hline & & \multicolumn{5}{c}{$o b$ Genotype } \\
\cline { 3 - 7 } Traits & Unit & TT & $\begin{array}{c}\text { Standard } \\
\text { error }\end{array}$ & TC & $\begin{array}{c}\text { Standard } \\
\text { error }\end{array}$ & $\mathrm{P}>\mathrm{F}$ \\
\hline LMP & $(\%)$ & 56.8895 & 0.3711 & 56.3297 & 0.5759 & 0.3647 \\
BT & $(\mathrm{mm})$ & 12.1169 & 0.3697 & 11.7562 & 0.5694 & 0.5517 \\
Ham & $(\mathrm{kg})$ & 8.5251 & 0.0316 & 8.5300 & 0.0580 & 0.9438 \\
Loin & $(\mathrm{kg})$ & 5.8074 & 0.0459 & 5.8437 & 0.0777 & 0.6802 \\
Shoulder & $(\mathrm{kg})$ & 3.9330 & 0.0305 & 4.0699 & 0.0488 & 0.0121 \\
Belly & $(\mathrm{kg})$ & 3.4107 & 0.0315 & 3.3145 & 0.0527 & 0.1080 \\
WRA & $(\%)$ & 2.5928 & 0.1722 & 2.6630 & 0.3156 & 0.8508 \\
Texture & $(\mathrm{kg})$ & 1.8201 & 0.2044 & 2.6182 & 0.3319 & 0.0322 \\
L color & - & 45.2864 & 0.7940 & 44.2750 & 1.0170 & 0.2572 \\
A color & - & 12.2806 & 0.3802 & 12.8777 & 0.5161 & 0.2207 \\
B color & - & 12.3567 & 0.1386 & 12.4174 & 0.2589 & 0.8417 \\
IMF & $(\%)$ & 0.4279 & 0.0517 & 0.3460 & 0.0745 & 0.3815 \\
\hline & & & & & &
\end{tabular}

are in accordance with Franco's (1999) regarding lean meat percentage and ham and shoulder weight in Pietrain.

Since all meats underwent the same treatment, and yet the Large White and Pietrain races presented greater B color values, which means yellowness or oxidated myoglobin, this may suggest that they have a lower bench life than the Landrace meat.

The Pietrain race presented a higher intramuscular fat value than the other races, meaning greater juiciness and better taste, as previously noted by Upnmoor (1997).

The Landrace breed presented a thicker carcass backfat layer, and a tendency to bigger belly weight, accompanied by a lesser carcass quality.

Table VIII - Least square means (of traits) and standard error (SE) values by race effect in purebred animals (equal letters at the horizontal mean absence of significant effect).

\begin{tabular}{|c|c|c|c|c|c|c|c|}
\hline \multirow[b]{2}{*}{ Traits } & \multirow[b]{2}{*}{ Unit } & \multicolumn{6}{|c|}{ Race } \\
\hline & & Pietrain & SE & Large white & SE & Landrace & SE \\
\hline LMP & $(\%)$ & $61.6938 \mathrm{a}$ & 0.7231 & $54.8698 \mathrm{~b}$ & 0.6051 & $53.2654 \mathrm{~b}$ & 0.5736 \\
\hline BT & $(\mathrm{mm})$ & $9.2318 \mathrm{c}$ & 0.7230 & $12.0672 \mathrm{~b}$ & 0.6014 & $14.5106 \mathrm{a}$ & 0.5707 \\
\hline Ham & $(\mathrm{kg})$ & $9.1603 \mathrm{a}$ & 0.0570 & $8.0178 \mathrm{c}$ & 0.0521 & $8.4045 b$ & 0.0509 \\
\hline Loin & $(\mathrm{kg})$ & $5.6178 b$ & 0.0860 & $5.9704 \mathrm{a}$ & 0.0763 & $5.8885 \mathrm{ab}$ & 0.0723 \\
\hline Shoulder & $(\mathrm{kg})$ & $4.2003 \mathrm{a}$ & 0.0587 & $4.0396 \mathrm{a}$ & 0.0502 & $3.7645 b$ & 0.0475 \\
\hline Belly & $(\mathrm{kg})$ & $3.1805 b$ & 0.0592 & $3.3597 \mathrm{~b}$ & 0.0522 & $3.5475 \mathrm{a}$ & 0.0494 \\
\hline WRA & $(\%)$ & $4.0501 \mathrm{a}$ & 0.3099 & $2.3369 b$ & 0.2837 & $1.4967 \mathrm{~b}$ & 0.2771 \\
\hline Texture & $(\mathrm{kg})$ & $2.6806 a$ & 0.3899 & $2.2482 \mathrm{a}$ & 0.3374 & $1.7286 a$ & 0.3187 \\
\hline L color & - & $45.3713 \mathrm{a}$ & 1.6744 & $45.6326 \mathrm{a}$ & 1.1976 & $43.3383 a$ & 1.1807 \\
\hline A color & - & $13.5202 \mathrm{a}$ & 0.7893 & $12.0214 \mathrm{a}$ & 0.5840 & $12.1958 \mathrm{a}$ & 0.5733 \\
\hline B color & - & $12.6195 \mathrm{ab}$ & 0.2498 & $12.7020 \mathrm{a}$ & 0.2288 & $11.8396 \mathrm{~b}$ & 0.2275 \\
\hline IMF & $(\%)$ & $0.6140 \mathrm{a}$ & 0.0821 & $0.3090 \mathrm{~b}$ & 0.0767 & $0.2379 b$ & 0.0778 \\
\hline
\end{tabular}


Table IX - Least square means (of the traits), standard error (SE) values and significance probability of each trait by sex effect, in purebred animals.

\begin{tabular}{lcccccc}
\hline & & \multicolumn{5}{c}{ Sex } \\
\cline { 3 - 6 } Traits & Unit & Male & SE & Female & SE & P > F \\
\hline LMP & $(\%)$ & 56.8041 & 0.4519 & 56.4151 & 0.4355 & 0.4152 \\
BT & $(\mathrm{mm})$ & 11.0842 & 0.4484 & 12.7889 & 0.4321 & 0.0005 \\
Ham & $(\mathrm{kg})$ & 8.4114 & 0.0423 & 8.6437 & 0.0410 & 0.0001 \\
Loin & $(\mathrm{kg})$ & 5.7042 & 0.0586 & 5.9470 & 0.0566 & 0.0007 \\
Shoulder & $(\mathrm{kg})$ & 4.1096 & 0.0378 & 3.8933 & 0.0364 & 0.0001 \\
Belly & $(\mathrm{kg})$ & 3.3656 & 0.0399 & 3.3595 & 0.0385 & 0.8945 \\
WRA & $(\%)$ & 2.0986 & 0.2302 & 3.1572 & 0.2233 & 0.0006 \\
Texture & $(\mathrm{kg})$ & 2.4985 & 0.2551 & 1.9398 & 0.2459 & 0.0527 \\
L color & - & 43.5337 & 0.8837 & 46.0277 & 0.8470 & 0.0004 \\
A color & - & 12.3262 & 0.4329 & 12.8321 & 0.4163 & 0.1697 \\
B color & - & 12.0048 & 0.1897 & 12.7693 & 0.1800 & 0.0020 \\
IMF & $(\%)$ & 0.4164 & 0.0615 & 0.3575 & 0.0582 & 0.4668 \\
\hline & & & & & &
\end{tabular}

The uncastrated male had the highest shoulder weight, and the female the biggest backfat thickness, ham and loin weight, as shown by Franco (1999) and Antunes (1997) (the latter only for ham and loin weight). Regarding meat quality, females presented greatest drip loss and $\mathrm{L}$ and $\mathrm{B}$ color values, meaning a worse meat quality as compared to the uncastrated male, and resulting in pale, yellow meat, similar to PSE meat rejected by consumers (Soares et al.,1998). As for carcass evaluation traits, the females presented the highest ham and loin values, which are, of course, desirable from the industrial point of view.

\section{Expected progeny differences $\mathrm{x}$ obese genotyping}

The statistical parameters of the comparison between genotype and EPD data and the variance analysis of fifty-four Landrace females and forty-nine Large White males, along with the EPDs, are presented in Tables X and XI, respectively.

The obesity genotype did not influence any traits. These results confirm those obtained by Hardje et al. (1998) on the correlation between the obesity genotype with daily gain, backfat, feed efficiency and meat $\mathrm{pH}$, where the authors found no significant differences in neither of the Landrace, Large White and Pietrain races.

The means of the EPD traits across genotypes for Landrace females and Large White males are presented in Table XII.

We concluded that allele $\mathrm{C}$ may be associated with fat accumulation, due to its highest frequency in the Piau race. The obesity gene did not influence any of the carcass evaluation traits of the crossbred animals, but in purebred animals it influenced shoulder weight and meat texture, whereas the TC genotype was associated with highest meat
Table X - Variance analysis of EPD (expected progeny difference) traits for daily weight gain (DWG), backfat thickness (BT) and litter size (LS) by obesity genotype effect in Landrace females.

\begin{tabular}{lcccc}
\hline & & \multicolumn{3}{c}{ Type III SS } \\
\cline { 3 - 5 } Source & GD & EPD DWG & EPD BT & EPD LS \\
\hline$o b$ gene & 1 & 90.7088 & 0.0404 & 0.0276 \\
Error & 52 & & & \\
\hline Total & 53 & & & \\
\hline
\end{tabular}

Table XI - Variance analysis of EPD (expected progeny differences) traits for daily weight gain (DWG), backfat thickness (BT) and litter size (LS) by obesity genotype effect in Large White males.

\begin{tabular}{lcccc}
\hline & & \multicolumn{3}{c}{ Type III SS } \\
\cline { 3 - 5 } Source & GD & EPD DWG & EPD BT & EPD LS \\
\hline$o b$ gene & 1 & 385.1326 & 0.0441 & 0.01692 \\
Error & 47 & & & \\
\hline Total & 48 & & & \\
\hline
\end{tabular}

Table XII - Least square means of EPD daily weight gain (DWG), backfat thickness (BT) and litter size (LS) for obesity genotype effect in Landrace females and Large White males.

\begin{tabular}{lcccc}
\hline & \multicolumn{2}{c}{ LD female } & \multicolumn{2}{c}{ LW male } \\
\cline { 2 - 5 } Traits & TT & TC & TT & TC \\
\hline EPD DWG & 23.0140 & 25.6517 & 37.9692 & 30.3840 \\
EPD BT & -0.1143 & -0.1700 & -0.2124 & -0.2936 \\
EPD LS & 0.0998 & 0.1458 & -0.0514 & -0.0011 \\
\hline
\end{tabular}

productivity and worst meat quality. In Large White males and Landrace females, the obesity gene did not influence any EPD trait (daily weight gain, backfat thickness, and litter size).

\section{Acknowledgments}

This study was supported by grants from CNPq. We thank Granja Rezende for providing blood samples and animal data.

\section{References}

Antunes RC (1997) O efeito do genótipo HAL sobre o rendimento de carne em partes da carcaça de suínos cruzados. Tese de Mestrado. Pós-Graduação em Genética e Bioquímica. Universidade Federal de Uberlândia.

Barinaga M (1996) Researchers nail down leptin receptor. Science 271:913-1996.

Bidwell CA, Ji S, Frank GR, Cornelius SG and Willis GM (1997) Cloning and expression of the porcine obese gene. Animal Biotechnology 8:191-206.

Cavalcanti SS (1984) Produção de suínos. Instituto Campineiro de Ensino Agrícola (ICEA) Gráfica e Editora Ltda, Campinas. 
Cusin I, Sainsbury A, Doyle P, Rohner-Jeanrenaud F and Jeanrenaud B (1995) The $o b$ gene and insulin. A relationship leading to clues to the understanding of obesity. Diabetes 44:1467-1470.

Elizondo G, Addis PB, Rempel WE, Madero C, Martin F, Anderson DB and Marple DN (1976) Stress response and muscle properties in Pietrain (P), Minnesota no. 1 (M) and PXM Pigs. Journal of Animal Science 43:1004-1014.

Ellis M, Webb A, Avery PJ and Browmn I (1996) The influence of terminal sire genotype, sex, slaughter weight, feeding regime and slaughter-house on growth performance, and carcass and meat quality in pigs, and on the organoleptic properties of fresh pork. Animal Science 62:521-530.

Felicio PED (1986) ABC do PSE/DFD. Alimentos e Tecnologia.

Franco MM (1999) Estudo da relação do polimorfismo dos genes Hal e GH com características de carcaça e qualidade da carne em 3 raças de suínos. Tese de Mestrado. Pós-Graduação em Genética e Bioquímica. Universidade Federal de Uberlândia.

Friedman JM (1997) The alphabet of weight control. Nature 385:119-120.

Hardje T, Kopke K, Wimmers K and Leuthold G (1998) Association between polymorphism of the leptin gene (LEP) and performance traits in a porcine resource family and in commercial outbred populations. Animal Genetics 29:60-74.

Houseknecht KL, Baile CA, Matteri RL and Spurlock ME (1998) The Biology of Leptin: A Review. Journal of Animal Science 76:1405-1420.
Pelleymounter MA, Cullen MJ, Baker MB, Hetch R, Winters D, Boone T and Collins, F (1995) Effects of the obese gene product on body weight regulation in ob/ob mice. Science 269:540-543.

Ramsay TG, Yan X and Morrison C (1998) The obesity gene in swine: sequence and expression of porcine leptin. Journal of Animal Science 76:484-490.

SAS User's Guide (1996) Statistical Analysis Systems.

Sellier P (1995) Genetics of pork quality. Resumos: 1-35. I Conferência Internacional sobre Ciência e Tecnologia de Produção e Industrialização de Suínos. Campinas, Brasil.

Soares Al, Ida EI, Olivo R and Shimokomaki M (1998) Benefícios da utilização da vitamina $\mathrm{E}$ na dieta dos animais para o controle da cor e rancidez das carnes. Revista Nacional da Carne 259:18-22.

Stratil A, Peelman LJ, Vanpoucke M and Cepica S (1997) A HinfI PCR-RFLP at the porcine leptin (LEP) gene. Animal Genetics 28:370-383.

Upnmoor, I (1997) Marmorização da carne suína. Suinocultura Industrial 127:30-32.

Visscher PM and Haley CS (1998) Strategies for marker-assisted selection in pig breeding programmes. Proc. $6^{\text {th }}$ World Congr. Genet. Appl. Livestock Prod. 23:503-510.

Wood JD, Jones RCD, Francombe MA and Whelehan OP (1986) The effects of fat thickness and sex on pig meat quality with special reference to the problems associated with overleanness. Animal Production 43:535-544.

Zhang Y, Proenca R, Maffei M, Barone M, Leopold L and Friedman JM (1994) Positional cloning of the mouse obese gene and its human homologue. Nature 372:425-431. 